\begin{abstract}
Iranica
Abstracta Iranica Revue bibliographique pour le domaine irano-aryen

Volume 34-35-36 | 2017

Comptes rendus des publications de 2011-2013
\end{abstract}

\title{
Edward DĄbrowa. Were the Arsacids Deities 'Revealed'?
}

\section{Fabrizio Sinisi}

\section{(2) OpenEdition \\ Journals}

\section{Electronic version}

URL: http://journals.openedition.org/abstractairanica/42344

DOI: 10.4000/abstractairanica.42344

ISSN: 1961-960X

\section{Publisher:}

CNRS (UMR 7528 Mondes iraniens et indiens), Éditions de l'IFRI

\section{Electronic reference}

Fabrizio Sinisi, «Edward Dąbrowa. Were the Arsacids Deities 'Revealed'? », Abstracta Iranica [Online], Volume 34-35-36 | 2017, document 55, Online since 30 July 2017, connection on 26 September 2020 URL : http://journals.openedition.org/abstractairanica/42344 ; DOI : https://doi.org/10.4000/ abstractairanica.42344

This text was automatically generated on 26 September 2020.

Tous droits réservés 


\title{
Edward DĄbrowa. Were the Arsacids Deities 'Revealed'?
}

\author{
Fabrizio Sinisi
}

\section{REFERENCES}

Edward DĄbrowa. « Were the Arsacids Deities 'Revealed'? », in: B. Virgilio, ed., Studi Ellenistici 24, Pisa-Roma, Fabrizio Serra Editore, 2011, p. 223-230.

1 The use of the appellative of Epiphanes was introduced in Arsacid coin titolature by Artabanus I (c. 126-122 BCE), son of Mithradates I, aiming at conveying the message that he belonged to a family with divine status. After Mithradates II, it featured regularly in the titolature until the end of the dynasty. The religious dimension connected to the royal aspirations to divinity implied by the initial use of the title were lost when the Arsacid kings had to change their priorities in the struggles for power following the death of Mithradates II, focusing on supporting their claims to the throne. After that, the title had the function of proof of the royal status and confirmation of the religious charisma of the rulers.

\section{AUTHORS}

\section{FABRIZIO SINISI}

Österreichische Akademie der Wissenschaften 